\title{
PERPINDAHAN MEREK AKIBAT KETIDAKPUASAN KONSUMEN DALAM PEMILIHAN PRODUK SMARTPHONE
}

\author{
Nuruni Ika Kusuma Wardhaniika ${ }^{1^{*}}$, Ignatia Martha Hendrati ${ }^{2}$ \\ Fakultas Ekonomi dan Bisnis UPN Veteran Jatim \\ Jl. Raya Rungkut Madya Gunung Anyar Surabaya 60294 \\ Email: ikanuruni.mnj@upn.jatim.ac.id ${ }^{1}$, ignatia.hendrati.ep@upnjatim.ac.id ${ }^{2}$ \\ *Penulis Korespondensi
}

\begin{abstract}
Abstrak
Penelitian ini dilatarbelakangi oleh penurunan penjualan dan pangsa pasar smartphone Android pada periode tertentu yang mengidentifikasi fenomena pergeseran pengguna smartphone dengan merek tertentu yang memiliki sistem operasi Android ke smartphone merek lain dengan sistem operasi lain. Tujuan dari penelitian ini adalah untuk mengetahui pengaruh atribut produk, ketidakpuasan konsumen, dan citra merek, dan persepsi harga terhadap pergeseran merek smartphone Android Xiaomi ke smartphone lain. Populasi dalam penelitian ini adalah pengguna Xiaomi di WTC (World Trade Center) Surabaya. Pengambilan sampel dalam penelitian ini menggunakan metode nonprobability sampling dengan teknik purposive sampling. Metode analisis statistik yang digunakan adalah teknik analisis Partial Least Square. Hasil analisis menunjukkan bahwa ketidakpuasan konsumen berpengaruh positif dan signifikan terhadap perpindahan merek. Citra merek memiliki pengaruh yang signifikan dan signifikan terhadap perpindahan merek. Persepsi harga berpengaruh negatif, tetapi tidak signifikan terhadap peralihan merek.
\end{abstract}

Kata Kunci: Perpindahan merek, ketidakpuasan konsumen, smartphone.

\begin{abstract}
This research was motivated by a decrease in sales and market share of Android smartphones in a certain period that identified the phenomenon of the shift of smartphone users with certain brands that have Android operating systems to other brands of smartphones with other operating systems. The purpose of this study was to determine the effect of product attributes, consumer dissatisfaction, and Brand image, and price perception on the shift of the Xiaomi Android smartphone brand to other smartphones. The population in this study was the Xiaomi user at WTC (World Trade Center) Surabaya. Sampling in this study used the nonprobability sampling method with the purposive sampling technique. The statistical analysis method used was the analysis technique Partial Least Square. The results of the analysis showed that consumer dissatisfaction had a positive and significant influence on brand switching. Brand image had a significant and significant influence on brand switching. Price perception had a negative but not significant effect on brand switching.
\end{abstract}

Keywords: Brand switching, customer disatisfaction, smartphone.

\section{Pendahuluan}

Keberadaan ponsel smartphone (telepon pintar) selalu ditunggu oleh konsumen karena smartphone beragam produk. Perusahaan selalu mengembangkan produk yang akan segara dipasarkan, yaitu dengan melihat serta menyesuaikan kebutuhan dan keinginan konsumen di masa yang akan datang. Untuk pengembangan produk selalu dilakukan oleh setiap perusahaan smartphone baik dari segi bentuk (desain) yang cantik, canggih, ukuran, fasilitas kegunaan, harga yang semakin terjangkau, dan lain sebagainya.

Untuk perusahaan masuk ke dalam kelas smartphone ini semakin membuat persaingan bisnis menjadi semakin ketat. Dikarenakan banyak model dan seri yang sangat bervariasi dan memberikan 
berbagai manfaat dan keunggulan dari setiap produk. Perusahaan smartphone Xiaomi digemari oleh konsumen karena Xiaomi memiliki banyak fitur praktis. Fitur praktis yang menjadi favorit antara lain Mi-Remote yang menjadi pengganti remote ketika konsumen lupa meletakkan remote. Xiaomi adalah smartphone pertama yang menciptakan fitur Mi-Remote tersebut. Mi-Remote adalah aplikasi andalan Xiaomi yang menggunakan IR Blaster. IR Blaster merupakan unsur wireless, sehingga perintah disalurkan dari smartphone ke televisi. Mi-Remote pada smartphone Xiaomi sendiri selain bisa digunakan untuk televisi bisa juga digunakan untuk remote AC, Proyektor, DVD player dan lain-lain. Ketika menggunakan Mi-Remote tidak perlu khawatir karena semua merek TV AC sudah terdaftar pada MiRemote.

Konsumen banyak menyebutnya Xiaomi user interface karena Xiaomi mempunyai kelebihan pada kameranya bagus baik dari depan maupun dari belakang. Seperti halnya Xiaomi Mi 5 yang memiliki kamera belakang 16 MP dan ditambah dengan optical image stabilizer yang membuat foto menjadi tajam dan tidak kabur. Redmi Note 3 dan Redmi Note 4 memiliki fitur beauty pada kamera yang berguna untuk mempercantik wajah di saat selfie. Fenomena yang terjadi belakangan ini yaitu smartphone Xiaomi pada tahun 2017 sampai 2019 Xiaomi Indonesia mengalami penurunan market share. Market share smartphone Xiaomi disajikan dengan data oleh International Data Corporation (IDC), sebagaimana terlihat dalam Tabel 1.

Tabel 1

Top Five Smartphone Market Share in Indonesia 2018-2019

\begin{tabular}{ccc}
\hline Tahun & 2018 & 2019 \\
\hline Samsung & $27 \%$ & $19,4 \%$ \\
Xiaomi & $20,7 \%$ & $12,5 \%$ \\
Oppo & $19,7 \%$ & $26,2 \%$ \\
Vivo & $11,8 \%$ & $22,8 \%$ \\
Realme & $1,6 \%$ & $12,6 \%$ \\
\hline
\end{tabular}

Sumber: International Data Corporation (IDC), 2019

Dari Tabel 1 diketahui bahwa Xiaomi pada tahun 2018 memiliki market share 20,7\%. Pada tahun 2019 menurun menjadi 12,5\%. Penurunannya sebesar 8,2\%. Hal itu menyebabkan permasalahan Xiaomi terutama pada hardware, Xiaomi Redmi 2 yang tiba-tiba menjadi panas meskipun tidak digunakan. Xiaomi tidak memiliki garansi resmi dari Indonesia, akibatnya ketika terjadi kerusakan pada handphone (HP) Xiaomi tidak akan bisa diperbaiki di gerai resmi. Selain pada hardware Xiaomi juga memiliki permasalahan dengan software yaitu ROM yang tidak jelas. Karena banyak HP Xiaomi yang bergaransi distributor, maka dari itu memiliki ROM yang tidak jelas karena ROM MIUI-nya tidak resmi, sehingga bisa menyebabkan munculnya iklan, baterai boros, tidak bisa upgrade, dan aplikasi tidak jalan. Hal tersebut membuat penggunanya gelisah dan bingung. Xiaomi memiliki harga jual yang cukup rendah untuk dijual (10 kelebihan dan kelemahan HP Xiaomi harga murah dengan spesifikasi canggih, 2019, Januari 9). Dengan kelebihan dan kecanggihan fitur yang seperti itu, maka fenomena berpindah merek atau brand switching (perpindahan merek) banyak ditemui pada konsumen Indonesia, terutama pada smartphone. Konsumen dapat berpindah pindah dari produk satu ke produk yang lain. Saat ini konsumen jarang sekali ada yang menetap pada satu brand tertentu. Konsumen lebih memilih berpindah merek karena mendapatkan manfaat yang diinginkan oleh konsumen tersebut (Kotler, 2016).

Perpindahan merek dapat terjadi karena adanya ketidakpuasan yang dialami pasca pembelian. Ketidakpuasan konsumen ini muncul karena konsumen memiliki ekspektasi atau harapan yang tinggi terhadap sebuah produk. Hal ini menunjukkan bahwa kepuasan pengguna merupakan salah satu faktor perpindahan merek (Kotler \& Keller, 2008). Faktor lain yang mempengaruhi konsumen untuk berpindah merek adalah citra merek. Citra merek merupakan sekumpulan asosiasi terhadap suatu merek yang berada di dalam benak atau ingatan konsumen (Schiffman \& Kanuk, 2007). Tujuan perusahaan adalah menghasilkan citra positif dari merek tersebut dengan cara membangun dan menciptakan hal positif terhadap suatu merek (Lin et al., 2013 dalam Pelupessy, Wardana, \& Suprapti 2017). Faktor selanjutnya yang membuat konsumen untuk melakukan perpindahan merek yaitu persepsi harga. Persepsi harga menurut Rangkuti (2008) merupakan biaya relatif yang harus konsumen keluarkan untuk menda- 
patkan produk atau jasa yang mereka butuhkan atau inginkan. Persepsi atas harga meliputi bagaimana informasi harga dimengerti oleh konsumen dan bermakna bagi mereka (Peter \& Olson, 2014).

\section{Kajian Teoritis dan Hipotesis \\ Perpindahan Merek}

Menurut Peter dan Olson (2014) perpindahan merek (brand switching) adalah pola pembelian yang dikarakteristikkan dengan perubahan atau pergantian dari satu merek ke merek yang lain. Munculnya perilaku brand switching dipengaruhi oleh beberapa faktor yaitu munculnya produk-produk baru konsumen berpindah untuk mengkonsumsi produk baru dan meninggalkan produk lama untuk mendapatkan kualitas dan kepuasan yang lebih baik dari produk sebelumnya. Indikator perpindahan merek menurut Indarwati dan Untarini (2017), yaitu:

1. Ketidaksediaan menggunakan produk ulang

2. Lebih memilih merek lain

3. Kepuasan setelah berpindah merek

\section{Ketidakpuasan}

Peter dan Olson (2014), mengemukakan apabila daya guna produk lebih rendah dari yang diinginkan, maka ketidakpuasan itu terjadi. Dengan demikian mengakibatkan konsumen tidak puas akan produk yang sudah dibelinya. Apabila konsumen merasa tidak puas biasanya konsumen akan mengganti dengan produk atau merek lain dan mengadukan keluhan kepada produsen barang, pengecer, dan konsumen lain. Ketidakpuasan konsumen dapat timbul karena adanya proses informasi dalam evaluasi terhadap suatu merek. Menurut Kotler dan Keller (2016) menyatakan bahwa ketidakpuasan konsumen terjadi apabila kinerja suatu produk tidak sesuai dengan persepsi dan harapan konsumen. Indikator yang mencirikan ketidakpuasan konsumen menurut Indarwati dan Untarini (2017), sebagai berikut:

1. Adanya keluhan yang dirasakan

2. Ketidaksesuaian kualitas dan harapan

3. Pengalaman negatif

\section{Citra Merek}

Citra merek menurut Kotler dan Keller (2016) adalah persepsi konsumen tentang suatu merek sebagai refleksi dari asosiasi yang ada pada pikiran konsumen. Citra merek merupakan asosiasi yang muncul dalam benak konsumen ketika mengingat suatu merek tertentu. Asosiasi tersebut secara sederhana dapat muncul dalam bentuk pemikiran dan citra tertentu yang dikaitkan dengan suatu merek. Indikator yang mencirikan citra merek yang digunakan dalam penelitian ini menurut Setiawan, Minarsih, dan Fathoni (2016), yaitu:

1. Lambang atau logo merek mudah diingat

2. Merek mudah dikenali (terkenal)

3. Merek yang terpercaya

4. Populer

5. Modern

\section{Persepsi Harga}

Peter dan Olson (2014) mengemukakan persepsi atas harga meliputi bagaimana informasi harga dapat dipahami oleh konsumen dan bermakna bagi mereka. Ketika kognitif harga bekerja, konsumen akan membandingkan antara harga yang dinyatakan dengan sebuah harga atau kisaran harga yang konsumen bayangkan terhadap suatu produk. Harga yang dipikirkan sebagai bahan untuk membuat perbandingan disebut harga acuan internal. Harga acuan internal merupakan harga yang dianggap pantas oleh konsumen atau harga yang dibayangkan oleh konsumen sebagai acuan harga pasar yang tinggi atau rendah. Dengan kata lain harga acuan internal menjadi semacam panduan untuk konsumen dalam mempertimbangkan harga apakah harga tersebut dapat diterima apa tidak oleh konsumen. Indikator yang mencirikan persepsi harga yang dikemukakan oleh Setiawan et al. (2016), yaitu:

1. Harga terjangkau

2. Harga sesuai kualitas 
3. Harga bersaing

4. Kesesuaian harga dengan manfaat

5. Potongan harga.

\section{Pengaruh Ketidakpuasan Konsumen Pada Perpindahan Merek}

Ketidapuasan dirasakan konsumen membuat perilaku peralihan merek. Dharmmesta (2002) mengemukakan bahwa kemampuan diterimanya merek mempunyai ketentuan utama yaitu kepuasan yang ditempuh konsumen ketika membeli. Ketidakpuasan konsumen disebabkan karena harapan konsumen tidak setara alias lebih tinggi dibandingkan hasil yang didapatkannya.

\section{Pengaruh Citra Merek Pada Perpindahan Merek}

Menurut Kotler (2002), Citra Merek bagaikan sebuah keyakinan, ide, beserta kesan yang dipikirkan oleh sesorang pada suatu merek. Citra Merek selalu memastikan sikap dan tindakan konsumen. Konsumen menganggap sebuah merek akan mempengaruhi suatu preferensi pada merek-merek yang ada di hadapannya. Memilih merek yang sesuai dengan keinginan dan kebutuhannya adalah tujuan konsumen. Persepsi yang positif dibentuk dari kualitas sebuah merek. Jika persepsi konsumen terhadap suatu produk negatif akan membuat produk tidak digemari serta tidak akan lama.

\section{Pengaruh Persepsi Harga Pada Perpindahan Merek}

Hawkins dan Mothersbaugh (2010) mengungkapkan bahwa salah satu penyebab konsumen beralih merek ialah masalah yang berhubungan atau berkaitan dengan harga. Apabila harga yang dianggap oleh konsumen tidak bisa memberikan manfaat yang sesuai dengan harapannya, maka konsumen akan beralih ke merek lain atau merek pesaing.

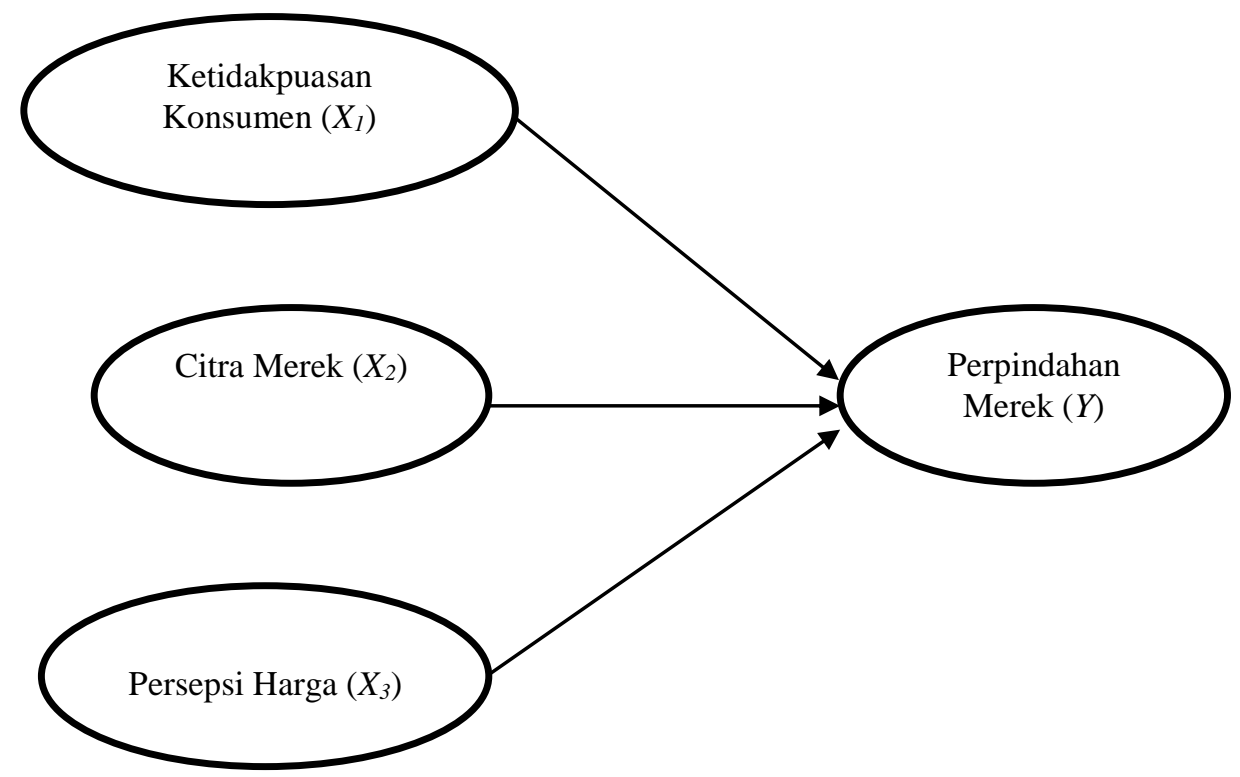

\section{Gambar 1. Kerangka konseptual}

\section{Hipotesis}

Sesuai dengan perumusan masalah dari landasan teori jadi hipotesis yang diangkat pada penelitian ini ialah:

$H_{l}$ : Ketidakpuasan konsumen berpengaruh positif pada perpindahan merek smartphone Xiaomi ke smartphone lain.

$H_{2}$ : Citra merek berpengaruh negatif pada perpindahan merek smartphone Xiaomi ke smartphone lain.

$H_{3}$ : Persepsi harga berpengaruh negatif pada perpindahan merek smartphone Xiaomi ke smartphone lain. 


\section{Metode Penelitian \\ Definisi Operasional Variabel}

Menurut Silalahi (2015) definisi operasional merupakan suatu definsi yang berkaitan kepada suatu variabel dengan cara memberikan arti atau mendefinisikan kegiatan, ataupun memberikan suatu operasional yang diperlukan dalam mengukur variabel. Definisi operasional setiap variabel yang digunakan dalam penelitian ini, sebagai berikut:

\section{Ketidakpuasan Konsumen $\left(X_{1}\right)$}

\section{Variabel Independen $(X)$}

Ketidakpuasan adalah adanya ketidaksesuaian harapan yang dirasakan seseorang setelah membandingkan kinerja atau outcome terhadap suatu produk. Pengukuran ketidakpuasan dalam penelitian ini menggunakan indikator yang digunakan dalam penelitian Indarwati dan Untarini (2017), yaitu:

- Adanya keluhan yang dirasakan $\left(X_{1.1}\right)$

Merupakan sambatan atau hal buruk yang dirasakan konsumen ketika menggunakan suatu produk.

- Ketidaksesuaian kualitas dan harapan $\left(X_{1.2}\right)$

Merupakan konsumen pasti akan merasa tidak puas jika produk yang mereka gunakan tidak sesuai dengan kualias dan harapan yang mereka inginkan.

- Pengalaman negatif $\left(X_{1.3}\right)$

Merupakan baik pengalaman yang negatif atau positif dari konsumen adalah hal yang sangat penting untuk membangun kepercayaan konsumen pada suatu produk.

\section{Citra Merek $\left(X_{2}\right)$}

Citra merek merupakan seperangkat keyakinan mengenai suatu barang atau jasa. Citra merek diukur berdasarkan penelitian Setiawan et al. (2016).

- Lambang atau logo merek yang mudah diingat $\left(X_{2.1}\right)$

Merupakan logo merek harus mudah diingat oleh masyarakat.

- Merek mudah dikenali $\left(X_{2.2}\right)$

Merupakan logo merek harus mudah dikenali oleh masyarakat.

- Merek yang terpercaya $\left(X_{2.3}\right)$

Merupakan merek yang bisa dipercaya oleh konsumen.

- Populer $\left(X_{2.4}\right)$

Merupakan merek yang populer di kalangan masyarakat.

- Modern $\left(X_{2.5}\right)$

Merupakan merek yang modern di benak konsumen.

\section{Persepsi Harga $\left(\mathrm{X}_{3}\right)$}

Persepsi harga adalah sejauh mana informasi harga dapat dipahami oleh pelanggan dan membuat berarti bagi pelanggan. Adapun indikator yang diukur menggunakan penelitian Setiawan et al. (2016).

- Harga terjangkau $\left(X_{3.1}\right)$

Merupakan aspek penetapan harga yang dilakukan oleh produsen atau penjual yang sesuai dengan kemampuan beli konsumen.

- Harga sesuai kualitas $\left(X_{3.2}\right)$

Merupakan aspek penetapan harga yang dilakukan oleh produsen atau penjual yang sesuai dengan kualitas produk yang dapat diperoleh konsumen.

- Harga bersaing $\left(X_{3.3}\right)$

Merupakan penawaran harga yang diberikan oleh produsen atau penjual berbeda dan bersaing dengan yang diberikan oleh produsen lain pada satu jenis produk yang sama.

- Kesesuaian harga dengan manfaat $\left(X_{3.4}\right)$

Merupakan aspek penetapan harga yang dilakukan oleh produsen atau penjual yang sesuai dengan manfaat yang dapat diperoleh konsumen dari produk yang dibeli.

- Potongan harga $\left(X_{3.5}\right)$

Merupakan pengurangan harga produk dari harga normal dalam periode tertentu. 


\section{Perpindahan Merek}

\section{Variabel Dependen $(Y)$}

Perpidahan merek adalah tindakan mendapatkan alternatif yang lebih baik. Pengukuran ketidakpuasan dalam penelitian ini menggunakan indikator yang digunakan dalam penelitian Indarwati dan Untarini (2017):

- Ketidaksediaan menggunakan produk ulang $\left(Y_{l}\right)$

Merupakan konsumen sudah tidak ingin menggunakan kembali suatu produk.

- Lebih memilih merek lain $\left(Y_{2}\right)$

Merupakan konsumen lebih percaya dan memutuskan untuk memilih merek yang lainnya dari merek sebelumnya.

- Kepuasan setelah berpindah merek $\left(Y_{3}\right)$

\section{Populasi}

\section{Teknik Penentuan Sampel}

Populasi adalah wilayah generalisasi dan terdiri atas objek/ subjek serta mempunyai kuantitas dan karakteristik tertentu yang diterapkan guna dipelajari lalu dijadikan kesimpulan. Populasi pada penelitian ini yaitu semua pengguna smartphone Xiaomi kemudian beralih ke smartphone lain di WTC (World Trade Center) Surabaya.

\section{Sampel}

Menurut Arikunto (2015) sampel ialah bagian atau wakil populasi yang diteliti. Pengambilan sampel dalam penelitian ini menggunakan teknik purposive sampling, yaitu pengambilan sampel berdasarkan kriteria. Kriteria sampel dalam penelitian ini ialah:

- Responden berusia > 17 tahun.

- Responden telah melakukan perpindahan merek smartphone Xiaomi ke smartphone lain.

Karena jumlah populasi belum diketahui jumlahnya secara pasti, jadi teknik penentuan sampel yang digunakan ialah berdasarkan pedoman pengukuran sampel menurut Ghozali (2011), yaitu jumlah sampel ialah jumlah indikator dikali 5 hingga 10 parameter. Dengan demikian jumlah sampel dalam penelitian ini 16 (indikator) x $5=80$ responden.

\section{Teknik Analisis Data}

Analisis data dilaksanakan dengan menggunakan metode SEM berbasis komponen. Partial Least Square (PLS) sebagai alat analisis pada penelitian ini. Teknik Partial Least Square (PLS) digunakan karena alat analisis ini sering dipakai sebagai kausal - prediktif yang susah serta merupakan teknik yang cocok untuk dipakai dalam aplikasi prediksi dan pengembangan teori seperti pada penelitian ini.

PLS ialah pendekatan yang cocok untuk prediksi, hal ini terlihat pada kondisi indikator bersifat formatif. Dengan variabel laten seperti kombinasi linier dari indikatornya, maka perkiraan nilai dari variabel laten dapat mudah didapatkan. Jadi perkiraan nilai pada variabel laten yang dipengaruhinya juga dapat mudah didapatkan.

\section{Analisis Data dan Pembahasan \\ Karakteristik Responden Berdasarkan Jenis Kelamin}

Berdasarkan hasil dari penyebaran kuesioner kepada 80 responden, diperoleh gambaran responden berdasarkan jenis kelamin seperti terlihat dalam Tabel 2.

Tabel 2

Karakteristik Responden Berdasarkan Jenis Kelamin

\begin{tabular}{ccc}
\hline Jenis Kelamin & Jumlah & Persentase (\%) \\
\hline Laki-Laki & 35 & $43,8 \%$ \\
Perempuan & 45 & $53,6 \%$ \\
Total & 80 & $100 \%$ \\
\hline
\end{tabular}


Berdasarkan Tabel 2 dapat diketahui bahwa mayoritas responden yang berminat untuk melakukan perpindahan merek adalah perempuan. Artinya, konsumen perempuan banyak yang merasa tidak puas pada smartphone Xiaomi ini dibanding dengan konsumen laki-laki. Oleh sebab itu, konsumen perempuan cenderung untuk cepat melakukan perpindahan merek smartphone.

\section{Interpretasi Hasil PLS}

Dari Gambar 2 dapat dilihat besarnya nilai factor loading tiap indikator yang terletak di atas tanda panah di antara variabel dan indikator, juga bisa dilihat besarnya koefisien jalur (path coefficients) yang berada di atas garis panah antara variabel eksogen terhadap variabel endogen. Selain itu bisa juga dilihat besarnya $R$-Square yang berada tepat di dalam lingkaran variabel endogen (variabel perpindahan merek).

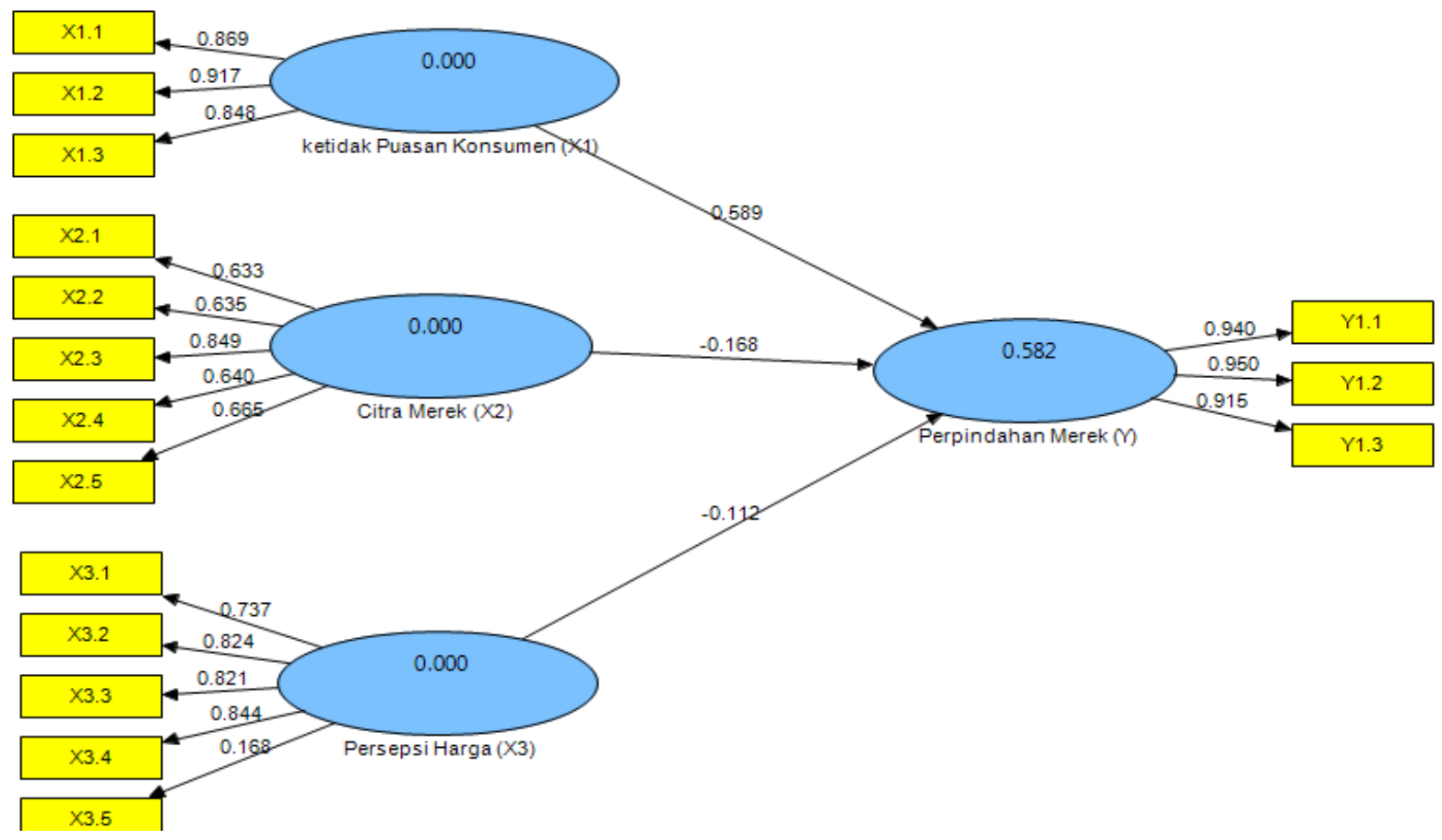

Gambar 2. Diagram jalur hasil output PLS

\section{Evaluasi Pengujian Struktural Model (Inner Model)}

Pengujian terhadap model struktural dilakukan degan melihat nilai $R$-Square yang merupakan uji goodness fit model. Pengujian inner model dapat dilihat dari nilai $R$-Square $\left(R^{2}\right)$ pada persamaan antar variabel laten. Nilai $R^{2}$ menjelaskan seberapa besar variabel eksogen (independen) pada model mampu menerangkan variabel endogen (varibel dependen/terikat).

Nilai $R^{2}=0,5817$ Hal ini dapat diinterpretasikan bahwa model mampu menjelaskan fenomena perpindahan merek yang dipengaruhi oleh variabel bebas antara lain ketidakpuasan konsumen, citra merek, dan persepsi harga dengan varian sebesar 58,17\%. Sisanya $(100 \%-58,17 \%)$ sebesar $41,83 \%$ dijelaskan oleh variabel lain di luar penelitian ini (selain ketidakpuasan konsumen, citra merek, dan persepsi harga).

\section{Tabel 3}

R Square

Ketidakpuasan Konsumen $\left(X_{1}\right)$

Citra Merek $\left(X_{2}\right)$

Persepsi Harga $\left(X_{3}\right)$

Perpindahan Merek $(Y)$

0,581753 
Tabel 4

\section{Hasil Dari Inner Weights}

Path Coefficients (Mean, STDEV, T-Values)

\begin{tabular}{lccccc}
\hline & $\begin{array}{c}\text { Original } \\
\text { Sample } \\
(\mathrm{O})\end{array}$ & $\begin{array}{c}\text { Sample } \\
\text { Mean } \\
(\mathrm{M})\end{array}$ & $\begin{array}{c}\text { Standard } \\
\text { Deviation } \\
(\text { STDEV) }\end{array}$ & $\begin{array}{c}\text { Standard } \\
\text { Error } \\
(\text { STERR) }\end{array}$ & $\begin{array}{c}\text { T Statistics } \\
(\mid \mathrm{O} / \mathrm{STERR})\end{array}$ \\
\hline $\begin{array}{l}\text { Ketidakpuasan Konsumen }\left(X_{1}\right)-> \\
\quad \text { Perpindahan Merek }(Y)\end{array}$ & 0,588514 & 0,585032 & 0,082252 & 0,082252 & 7,155024 \\
$\begin{array}{l}\text { Citra Merek }\left(X_{2}\right)->\text { Perpindahan Merek }(Y) \\
\begin{array}{l}\text { Persepsi Harga }\left(X_{3}\right)->\text { Perpindahan Merek } \\
(Y)\end{array}\end{array}$ & $-0,168063$ & $-0,167324$ & 0,071305 & 0,071305 & 2,356957 \\
& $-0,112429$ & $-0,121370$ & 0,066464 & 0,066464 & 1,691573 \\
\hline
\end{tabular}

1. Ketidakpuasan konsumen $\left(X_{I}\right)$ memiliki pengaruh positif pada perpindahan merek $(Y)$ dapat diterima, dengan path coefficients sebesar 0,5885 dan nilai T-statistic sebesar 7,1550 lebih besar dari nilai $Z \alpha=0,05(5 \%)=1,96$, maka signifikan (positif).

2. Citra merek $\left(X_{2}\right)$ memiliki pengaruh negatif pada perpindahan merek $(Y)$ dapat diterima, dengan path coefficients sebesar -0,1680 dan nilai $T$-statistic sebesar 2,3569 lebih besar dari nilai $Z \alpha=0,05(5 \%)=$ 1,96, maka signifikan (negatif).

3. Persepsi harga $\left(X_{3}\right)$ memiliki pengaruh negatif pada perpindahan merek $(Y)$ tidak dapat diterima, dengan path coefficients sebesar -0,1124 dan nilai T-statistic sebesar 1,6915 lebih besar dari nilai $Z \alpha=0,05(5 \%)=1,96$, maka tidak signifikan (negatif).

\section{Pembahasan \\ Pengaruh Ketidakpuasan Konsumen Pada Perpindahan Merek}

Penelitian telah dilaksanakan lalu diperoleh hasil bahwa ketidakpuasan konsumen mempunyai pengaruh positif dan signifikan pada perpindahan merek pada Smartphone Xiomi dapat diterima. Ketika konsumen meras semakin tidak puas dengan smartphone iaomi, maka keputusan untuk berpindah merek akan meningkat. Hal ini terjadi karena konsumen banyak yang mengeluh karena smartphone Xiaomi tidak sejalan dengan kualitas dan harapan konsumen. Smartphone Xiaomi memiliki masalah pada hardware yaitu handphone tiba-tiba menjadi panas meskupun tidak digunakan. Smartphone Xiaomi juga memiliki masalah pada software. Masih banyak smartphone Xiaomi yang dijual dengan garansi distributor dan memiliki ROM yang tidak jelas, sehingga MIUI-nya tidak resmi serta menyebabkan munculnya iklan, baterai boros, tidak bisa upgrade, dan aplikasi tidak jalan. Kemudian ketika Xiaomi mengalami kerusakan yaitu mati total, bahasa dan region pada Xiaomi ketika di-reset akan berubah menjadi bahasa China dan tidak bisa diganti bahasa Indonesia serta region juga akan berubah menjadi China pula.

Ketidakpuasan konsumen menjadi faktor yang bisa membuat konsumen beralih metek dari Xiaomi ke smartphone lain. Ketidakpuasaan konsumen muncul karena apa yang dirasakan oleh konsumen ketika menggunakan suatu produk tidak seperti apa yang diinginkan atau diharapkan konsumen, sehingga konsumen merasa tidak puas.

Hasil penelitian ini sesuai dengan penelitian yang dilakukan oleh Candra (2014) yang menyatakan bahwa ketidakpuasan konsumen mempunyai pengaruh positif dan signifikan pada Perpindahan Merek. Hasil ini juga sejalan dengan teori yang dikemukakan oleh Dharmmesta (2002), kepuasan yang dialami oleh konsumen ketika membeli merupakan pemasti utama dari kapasitas diterimanya merek. Ketidakpuasan konsumen disebabkan ketika pengharapan konsumen tidak setara alias lebih tinggi dibandingkan hasil yang diterimanya.

\section{Pengaruh Citra Merek Pada Perpindahan Merek}

Penelitian telah dilaksanakan lalu diperoleh hasil bahwa Citra Merek memiliki pengaruh negatif dan signifikan pada perpindahan merek Smartphone Xiomi dapat diterima. Semakin menurun citra merek smartphone Xiaomi, maka perpindahan merek akan meningkat. Hal ini terjadi karena smartphone Xiaomi memang smartphone yang mudah dikenali baik itu dari nama merek dan logonya serta merek yang terpercaya. Smartphone Xiaomi sudah menjalankan fungsi dari produknya, ketika konsumen beralih dari smartphone Xiaomi ke merek smartphone yang lain, maka konsumen hanya sekedar berpindah tanpa melihat citra merek dari smartphone Xiaomi itu sendiri. Konsumen sudah mengetahui 
bagaimana citra merek dari smartphone Xiaomi tersebut, sehingga ketika konsumen berpindah merek konsumen hanya sekedar berpindah merek. Hasil penelitian ini dikatakan negatif karena konsumen yang hanya sekedar berpindah ke merek lain tanpa melihat citra merek smartphone Xiaomi itu sendiri. Selain itu, konsumen juga lebih tertarik pada fitur produk pesaing atau merek lain yang lebih menarik dari smartphone Xiaomi. Hal itu yang membuat konsumen melakukan keputusan untuk berpindah merek.

Hasil penelitian ini tidak sejalan dengan penelitian yang dilakukan oleh Radamuri, Farida, dan Dewi (2013) menunjukkan bahwa citra merek memiliki pengaruh positif pada perpindahan merek, tetapi sejalan dengan teori yang dikemukakan oleh Kotler (2002) menyatakan bahwa citra merek sangat menentukan pandangan dan respon konsumen. Jika persepsi konsumen pada suatu produk negatif akan membuat produk tidak akan digemari serta tidak bertahan lama.

\section{Pengaruh Persepsi Harga Pada Perpindahan Merek}

Penelitian telah dilaksanakan lalu diperoleh hasil bahwa persepsi harga mempunyai pengaruh negatif dan tidak signifikan pada perpindahan merek smartphone Xiaomi tidak dapat diterima. Semakin rendah persepsi harga terhadap smartphone Xiaomi, maka perpindahan merek akan meningkat. Hal ini terjadi karena memang konsumen untuk melakukan perpindahan merek tidak terlalu memperhatikan persepsi harga, pada kenyataannya konsumen dalam melakukan perpindahan merek lebih berpikir mengenai kualitas smartphone Xiaomi. Kualitas smartphone Xiaomi menjadi hal yang lebih penting dari persepsi harga, karena dari kualitas smartphone Xiaomi tersebut bisa menentukan konsumen merasa puas atau tidak.

Hasil penelitian ini tidak sejalan dengan penelitian Nuromavita (2016) yang memperlihatkan bahwa persepsi harga mempunyai pengaruh positif pada perpindahan merek atau konsumen memutuskan berpindah merek dikarenakan faktor persepsi harga, juga tidak sesuai dengan teori Aaker (1991) yang mengungkapkan bahwa konsumen memutuskan perpindahan merek disebabkanoleh masalah harga. Harga suka dianggap sebagai indikator kapasitas bagi konsumen. Apabila harga tinggi, konsumen berpikir bahwa kualitas lebih baik.

Jadi, dalam melakukan perpindahan merek konsumen tidak dipengaruhi secara langsung oleh persepsi harga terhadap smartphone Xiaomi di WTC Surabaya. Sebagus apapun persepsi harga terhadap smartphone Xiaomi tidak mempengaruhi konsumen dalam melakukan perpindahan merek melainkan ada faktor lain yang dapat mempengaruhi konsumen yaitu kualitas dari smartphone Xiaomi dan bisa memberikan manfaat yang dibutuhkan oleh pengguna. Sesuai dengan kondisi di lapangan konsumen cenderung tidak hanya melihat harga smartphone Xiaomi, tetapi lebih melihat pada kualitas smartphone Xiaomi secara langsung.

\section{Simpulan, Keterbatasan, dan Saran Simpulan}

Ketidakpuasan konsumen memberikan kontribusi pada perpindahan merek pengguna smartphone Xiaomi di WTC Surabaya. Semakin konsumen merasa puas, maka akan semakin rendah perpindahan merek yang dilaksanakan oleh pengguna smartphone Xiaomi. Citra Merek tidak memberikan konstribusi pada perpindahan merek pengguna smartphone Xiaomi di WTC Surabaya. Semakin turun citra merek smartphone Xiaomi, maka akan semakin tinggi perpindahan merek yang dilakukan pengguna smartphone Xiaomi. Persepsi Harga tidak memberikan kontribusi terhadap perpindahan merek pengguna smartphone Xiaomi di WTC Surabaya. Sebaik apapun persepsi harga tidak akan berpengaruh signifikan terhadap perpindahan merek.

\section{Keterbatan Penelitian}

Keterbatasan dalam penelitian ini antara lain adalah keterbatasan mengenai objek penelitian yang hanya menggunakan tiga variabel dengan hanya membandingkan smartphone Xioami dengan smart lainnya, serta waktu yang relatif singkat selain keterbatasan yang utama masih terdapat banyak keterbatasan lainnya, untuk penelitian yang akan datang hendaknya melakukan replikasi pada jenis industry yang berbeda dan lebih luas, sehingga menarik untuk diteliti lebih lanjut. 


\section{Saran}

Beberapa saran yang dapat diberikan sebagai berikut. Konsumen bisa mengalami ketidakpuasan apabila kualitas dan kinerja sebuah produk tidak sesuai dengan yang mereka harapkan atau inginkan sebelumnya. Konsumen mengharapkan mendapatkan kualitas yang baik dari smartphone Xiaomi. Baterai yang tidak cepat panas ketika tidak digunakan, handphone tidak mati dengan sendirinya dan kinerja smartphone yang lebih baik lagi terhadap smartphone Xiaomi adalah harapan dari konsumen. Guna menghindari perpindahan merek, smartphone Xiaomi lebih meningkatkan dan memperbaiki kualitas produknya sesuai dengan yang diharapkan konsumen, maka tingkat perpindahan merek bisa rendah. Citra merek Xiaomi sudah cukup baik dan merupakan merek yang terpercaya bagi konsumen. Xiaomi hanya perlu meningkatkan kualitas produknya lagi agar konsumen tidak berpindah ke merek yang lain. Kesesuaian harga dengan manfaat merupakan penetapan harga yang dilaksanakan oleh penjual yang sebanding dengan manfaat yang didapatkan konsumen ketika membeli produk. Berdasarkan jawaban responden, smartphone Xiaomi harus lebih memperhatikan kesesuaian harga dengan manfaat yang diperoleh konsumen. Jadi, ketika konsumen sudah membeli smartphone Xiaomi akan merasakan harganya sudah cocok dengan manfaat yang didapatkan dan konsumen menjadi puas.

Referensi

Aaker, D. A. (1991). Managing brand equity: Capitalizing on the value of a brand name. New York, NY: The Free Press.

Arikunto. (2015). Prosedur penelitian suatu pendekatan praktik. Jakarta: Rineka Cipta.

Candra, J. (2014). Pengaruh faktor promosi, kualitas produk, dan ketidakpuasan terhadap perpindahan merek. Jurnal Ilmu Manajemen, 2(3), 857-867.

Dharmmesta, B. S. (2002). Perilaku beralih merek konsumen dalam pembelian produk otomotif. Jurnal Ekonomi dan Bisnis Indonesia, 17(3), 288-303.

Ghozali, I. (2011). Aplikasi analisis multivariate dengan Program IBM SPSS 19. Semarang: Badan Penerbit Universitas Diponegoro.

Hawkins, D. I., \& Mothersbaugh, D. L. (2010). Consumer behavior: Building marketing strategy. $11^{\text {th }}$ Edition. New York, NY: McGraw-Hill, Irwin.

Indarwati, Y., \& Untarini, N. (2017). Pengaruh ketidakpuasan terhadap keputusan perpindahan merek dengan kebutuhan mencari variasi sebagai variabel moderasi (Studi pada pengguna smartphone yang pernah melakukan perpindahan merek di Surabaya). Jurnal Ilmu Manajemen, 5(1), 1-11.

International Data Corporation. (2019). Smartphone market share. https://www.idc.com/promo/smar tphone-market-share/vendor

Kotler, P. (2002). Manajemen pemasaran. Edisi Milenium 1. Jakarta: PT. Prenhallindo.

Kotler, P., \& Keller, K. L. (2008). Manajemen pemasaran. Jilid 1. Jakarta: Penerbit Erlangga.

Prentice Hall, Inc.

10 kelebihan dan kelemahan HP Xiaomi harga murah dengan spesifikasi canggih. (2019, Jan 9). Liputan6. https://www.liputan6.com/tekno/read/3866994/10-kelebihan-dan-kelemahan-hp-xia omi-harga-murah-dengan-spesifikasi-canggih.

Nuromavita, I., \& Soliha, E. (2016). Pengaruh ketidakpuasan konsumen, citra merek dan persepsi harga terhadap perpindahan merek sepeda motor Yamaha ke Honda. Prosiding Seminar Nasional Multi Disiplin Ilmu Unisbank 2016, Semarang, Indonesia, July 2016, Stikubank University.

Pelupessy, S. J., Wardana, I. M., \& Suprapti, N. W. S. (2017). Peran brand image dalam memediasi pengaruh WOM terhadap switching intention ke produk smartphone merek Samsung Di Denpasar. E-Jurnal Ekonomi dan Bisnis Universitas Udayana, 6(5), 1939-1966.

Peter, J. P., \& Olson, J. C. (2014). Consumer behavior \& marketing strategy. $9^{\text {th }}$ Ed. New York, NY: McGraw-Hill Education.

Radamuri, G., Farida, N., \& Dewi, R. S. (2013). Pengaruh citra merek, word of mouth, dan iklan terhadap keputusan perpindahan merek. Jurusan Ilmu Administrasi Bisnis, 2(3), 380-386.

Rangkuti, F. (2008). The power of brands. Jakarta: Gramedia Pustaka.

Schiffman \& Kanuk. (2007). Perilaku konsumen. Edisi Kedua. Jakarta: PT. Indeks Gramedia.

Setiawan, H., Minarsih, M. M., \& Fathoni, A. (2016). Pengaruh kualitas produk, kualitas pelayanan dan kepercayaan terhadap kepuasan nasabah dan loyalitas nasabah dengan kepuasan sebagai 
variabel intervening (Studi kasus pada nasabah Koperasi Rejo Agung Sukses Cabang Ngaliyan). Jurnal of Management, 2(2).

Silalahi, U. (2015). Metode penelitian sosial kuantitatif. Bandung: PT. Refika Aditama. 